\title{
COVID-19: impact on quality of work life in real estate sector
}

\author{
Soumi Majumder ${ }^{1} \cdot$ Debasish Biswas $^{1}$
}

Accepted: 19 March 2021 / Published online: 24 March 2021

(C) The Author(s), under exclusive licence to Springer Nature B.V. 2021

\begin{abstract}
COVID-19 pandemic has been spread like wildfire and left its deadly impact throughout the world. This would harm businesses according to the sectors. Like other sectors real estate sector under the construction industry is also facing the impact of the COVID-19 pandemic. It becomes very detrimental about labour market, company liquidity, the supply of materials, project delivery, and key cost components, and so on. In general, it happens that the real estate sector often experiences complexities in case of project completion, scheduling, and financing. The planned work cannot be carried out due to the non-availability of sufficient numbers of skilled labours and staff. Moreover due to effects of pandemic real estate sectors and the work-life of real estate professionals are being hampered. It is very much obvious that human resources act as the lifeline of any organization and they need to be handled and managed with the utmost care and dignity. Despite the physical, technological and financial resources in the business, human resource is such a critical asset that employers should take care of their quality of work-life all the time, not only during the crisis period. By satisfying them the business can achieve its objectives in terms of revenue and recognition. After a strict lockdown when things return to new normal and employees return to work, the company needs to take certain 'human resource' perspectives for maintaining a good quality of work life. All the employers should implement some strategies concerning to qualitative work life of the employees during this epidemic situation. The real estate sector is labour intensive and employees are a very critical resource that helps to increase productivity and enhancing competitiveness in the market. The impact of the pandemic on the quality of work-life among real estate employees in Kolkata, India is also studied.
\end{abstract}

Keywords Pandemic $\cdot$ COVID-19 $\cdot$ Real estate $\cdot$ Quality of work-life $\cdot$ Employees · Employers · Organization

Soumi Majumder

majumdersoumihr@gmail.com

Debasish Biswas

debasish762010@yahoo.com

1 Department of Business Administration, Vidyasagar University, Midnapore, West Bengal, India 


\section{Introduction}

Quality of work-life (QWL) refers to the favorableness or unfavourableness of a job environment for the people working in an organization. Taylor's scientific management is a widely used theory in management to analyze and synthesizes workflows. The main objective of Frederick Taylor's scientific management is to improve labor productivity. Post era of scientific management, a revolutionary change has been noticed in the workflow for an organization to increase the efficiency and specialization of employees (a revolutionary move towards the analysis and synthesis of workflows) (Locke 1982). As the quality of work-life got more and more important, the employers redesigned and modified their respective jobs for providing them a good QWL, work stress reduction, relationship improvement with peers, motivating for teamwork, provide effective human resource development and learning environment creation for the employees (2020). QWL also shapes the job environment, methods of work, and its outcomes and also encourage the employees of all levels to participate actively in the organization (2020). The main objects of QWL are (i). create a positive attitude, (ii) increases productivity, (iii) improve the standard of living of the employee, and (iv). increases the effectiveness of the organization. Various recent studies show that the new path for employee retention in an organization can be increased by paying attention to the employee's demands/needs and then only; the company can be benefitted in terms of productivity, employee loyalty, and company reputation in long run (Phadtare 2010). QWL having a high influence on organizational effectiveness. In other words, QWL is the input of employee satisfaction and output as the economic strength of the organization. It is well established that the work-related conflicts can be handled and manageable by better QWL. Proper work balance helps to reduce the boredom, fatigue, and stress of employees. It is the responsibility of employers to provide them a good culture, sporting, or other activity that can be a benefit to the community and society at large (Lawler 1975). An employer should support the community activities and help employees to involve in such things. Quality of work-life automatically increases job satisfaction level and also the commitment level besides high productivity (Grachev and Rakitsky 2013). Any reputable organization needs to create a benchmark in the market as well as society. Therefore from an organization's perspective quality of work-life of employees is a very focusing paradigm for the success of the business.

The supply of materials, labour market, company liquidity, project delivery, key cost components on construction projects etc. (Shinde et al. 2020a) is highly impacted by COVID-19 pandemic. Construction sites across the Globe are closed because of lockdown. For health and safety reasons people makes themselves in-home quarantine. A sharp decrease has been observed in the production sector of various countries like India, Italy, China and many more. Because of non availability of Chinese made goods, materials and equipments, shortage of construction materials has been faced by the contractors and employers. The project completion is getting delayed or cancelled due to high cost of such materials, and equipments (Fong et al. 2020). A poor economic structure has been created in real estate sector and countries' infrastructure development faced a huge loss because of worldwide adverse impact of corona-virus. Around Rs.30,000 crore per day was the overall impact of novel corona-virus in the Indian construction sector as per the report of Klynveld Peat Marwick Goerdeller (KPMG) which reduces the investment on construction-related projects by $13-30 \%$ and creates a significant impact on employment as well as Gross Value added(Joshi et al. 2020). Besides this, KPMG (a well-known global network of professional firms providing Audit, Tax, and Advisory services) also reported that the estimated 
cost is increased by $20-25 \%$ and $10-15 \%$ for skilled employees and semi-skilled, unskilled employees respectively. It is interesting to note that, semi-skilled does not require advanced training and specialized skill like unskilled employees. In West Bengal, the 68 days lockdown started from March 24th, 2020 to May 31st, 2020 has created a huge lack in labor supply as all migrated laborers returned to their villages (Srivastava and Kanpur 2014; Mitcham 2005). The real estate companies are being impacted in terms of productivity, revenue generation, employees' performance, and their quality of work life. The work-life of real estate employees have been affected by this pandemic. The employer should preserve the value and liquidity during this crisis time. We know that the real estate sector is labour intensive and it has unique nature due to its complexity (Avkiran 2000). Work from home all the time is not possible for the sector. When it is coming to the reopening of work of real estate sector many people who are working various levels of management and various levels of experience are taken into consideration in our study. Human resources are the assets of the company, by satisfying them the organization can earn long-term revenue and run the sector efficiently (Baily et al. 1996). Therefore a light has been come up to the quality of work-life of these employees. In our study, we are highlighting the impact of COVID-19 on the quality of work-life in real estate construction employees.

In Sect. 2, we have reported the literature review and the objective of the study; the research methodology part has been discussed in Sect. 3. The analysis and interpretation part is reported in Sect. 4, findings and discussion are reported in Sect. 5 and finally, Sect.6 is the conclusion section.

\section{Literature review}

Many kinds of literature have been conducted on the quality of work-life in various sectors. Now the day's quality of work-life of the employees is a very significant issue. The researchers have been conducted their survey on this particular topic in various work sectors. We have jotted down the different excerpts on quality work-life in this segment. Some studies were conducted on unorganized sectors in Karnataka. This study established that employment security is one of the requirements to maintain a good quality of work life (Muchinsky 1977). Some policies were made on the survey in case of employment security in Karnataka. The study revealed due to the different occupational groups in different levels some problems had been occurred related to work life. The paper was based on the identification of the problems of quality of work-life and the techniques to solve these problems. Another descriptive study has been made on problems of women employees in the construction sector in Tiruchirapalli (Ralston and Flanagan 1985). In that study, the data were collected through a questionnaire. Non-probability convenient sampling was used. The study dealt with the components of quality of work-life for women employees. In Hariyana another study was conducted on women employees in the unorganized sector. The objective of the study was to know the socio-economic, working, and living conditions of the female employees. This study focused on fair and justified treatment especially on women who were working in the unorganized sector. The study revealed the existence of disparity in wages, working conditions, and harassment in the case of female employees at the workplace to provide a better quality of work-life. These parameters need to evaluate correctly for male and female both and change it accordingly (Khan et al. 2011).Apart from these, there are four important factors namely, work environment, salary, job security, and personal growth had been identified to evaluate the quality of work-life of employees, 
working in the construction real estate sector (Naithani 2010). It has been said that these four factors have a positive impact on job satisfaction and level of commitment among the employees. The study stated that organizations need to provide good learning opportunities for the skill development of employees. If the people of the organization possess a better quality of work-life they will be highly productive. Therefore firms need to be more focused on working life. To enhance performance level, the firms need to pay attention to the redressal of grievances. A grievance is a feeling of dissatisfaction relating to conditions of employment. If it is solved, it creates a smooth and efficient working environment to make the quality of work-life better. This study also focused on recruitment and retention of employees, training and development activities, different human resource policies, and other components of quality of work-life in house building sectors (Westwood et al. 2016). The construction workers faced some major problems like poor health conditions, poor working life, inadequate wage structure, long working hours, harassment, lack of fair treatment, lack of safety measures, lack of proper education for children, and so on (MayerSchonberger and Cukier 2013). It has been said in that study by the effective use of labour laws in this juncture the problems can be redressed related to employment. To feel the importance of quality of work-life another study was made in the telecom sector and it has been conducted to establish the relation between quality of work-life and its impact on job performance. The determinants, identified in this study were organizational culture, workplace relationship, training and development facilities, fringe benefits, reward system, autonomy, job security, variations in work schedule, and so on. This study focused on individual performance along with organizational performance and its relation with qualitative work life (Dey et al. 2018). We consider some research studies during the pandemic period also. The researchers made the study not only based on the quality of work-life also work-life balance in the era of the COVID-19 pandemic. The mentioned study analyzed the work-life balance of working women professionals in pandemic and also stated the problems and challenges faced by them. It is revealed that the professionals were able to continue the job through the work from home technique, as they were pushed to manage a family as well as their work during this crisis time. Work-life balance has got high importance in this time. This study relating to the pandemic situation discussed the methods of improvement about work from home (Swarnalatha and Lalitha (2020). Another study was made on the impact of work from home on employees during the lockdown. The investigation explored the nature of the current crisis of work along with the quality of work-life of the employees. In this study a depth interview took place with 24 middle and senior-level managers in manufacturing and technology-enabled service sectors in India. The study said that due to long working hours for work from home concept, the level of productivity has been decreased and the level of stress has been increased. Besides that sparks of creativity from the side of the employees also are missed during this isolation period. The researchers suggested from the study that organizational leaders need to revisit work-from home policies and other theoretical contributions. The quality of work-life is getting hampered; this should be improved during the pandemic (Jaiswal and Arun 2020).

Therefore from the above literature, we can able to evaluate the importance of quality of work-life in business. So many studies have been conducted on employees working life in different sectors, but very few studies have made on the real estate sector considering on pandemic situation under the construction industry. During this pandemic, the work-life of employees has become a striking issue in a business environment. To keep this in mind we have identified the research gap on the stated topic and decided to make our study on quality of work-life during the COVID-19 pandemic in the real estate sector in Kolkata. 


\subsection{Objective of the study}

Based on the several excerpts we have framed our objective of the study and that is.

I. To find out the impact of COVID-19 pandemic on quality of work-life in real estate professionals and real estate sectors.

Here null hypothesis is,

Ho There has no impact of the pandemic on the quality of work-life of real estate professionals.

Alternative Hypothesis is,

H1 There has an impact of a pandemic on the quality of work-life of real estate professionals.

\section{Research methodology}

The research methodology part is defined based on primary data, that has been collected from different real estate companies in Kolkata, India. Our study focused on employees' quality of work-life during a pandemic. Therefore the professionals of real estate organizations are taken into consideration for our study. Employees who are working in the top, middle and lower levels of management are the respondents in this study. We have collected the data through a structured questionnaire; apart from this observation method and interview methods of data collection are also used. Little information is taken from a secondary data source like research publications, magazines, etc.

\subsection{Sampling}

As per Polit and Hungler, 1989, sampling refers to the process of selecting a portion of the population to represent the entire population. It is a subset of a population selected to participate in the study. We have used a cluster random sampling method to select the employees. The questionnaires were distributed among 135 real estate professionals, 100 are taken into consideration among them.

\subsubsection{Sampling type}

cluster sampling method has been used to collect data. This is a type of probability sampling method. 


\subsubsection{Sampling frame}

The sample is taken from different head offices and sites in real estate companies. The demographic profiles of the respondents that have been collected from our study are age, gender, educational level, years of working experience, and managerial positions.

\subsection{Data collection}

A structured questionnaire and interview method are used for primary data collection. Secondary data is used in the form of information collected from various literature and case reports. Besides the interview schedule, the open-ended questionnaire is prepared mainly for project managers, supervisors, engineers at different sites who are looking after the overall coordination of these civil construction projects to know their views regarding the condition of work-life of different employees in their sites. Data was collected from employees of various large size real estate companies (Kolkata based) during the period of June-August 2020. Cluster sampling (is a probability sampling technique) is used to divide the population into multiple groups (clusters) for this study (Milligan et al. 2004). Cross-sectional data analysis is deployed to study particular variables of interest of the participants (one specific point in time) (Dahlin et al. 2005).

\section{Analysis}

The research hypothesis is framed based on the objective. We want to find out the impact of the COVID-19 pandemic on the quality of work-life of real estate professionals. We have considered twelve variables related to the quality of work-life during the epidemic situation. How organizations are taking care of their employees during this crisis period, these variables help to know that situation. These twelve variables are considered to measure the quality of work-life, such as the process of recruitment, employee morale, online learning practice, mental health, employees' performance, safety measures as per World Health Organization (WHO), insurance coverage, bonus, pay cut, career planning, termination, and employee commitment. We are sizing down the numbers of variables through a factor analysis test. The KMO test, Principal Component Analysis (PCA) test, Rotated component matrix are stated below. PCA is primarily used to reduce the dimensionality of large data sets. PCA helps to transform a large set of variables into a smaller one preserving most of the information in the large set (Virmani et al. 2016; Nandi et al. 2015; Kravchik and Shabtai 2021).

After that, we measure the impact of the quality of work-life during COVID-19 according to the level of experience of the respondents through the ANOVA test including the Bonferroni test (As we have reported multiple comparison tests in this study, the Bonferroni test is used for establishing the result statistically).

All tests are done by SPSS, version22. The demographic profile of the respondents has been described by bar diagrams.

Figure 1a has depicted the male and female ratio both are shown from the sample. The figure shows that more than 60 percentages are male and the rest are female in the study. In Fig. 1b, we have divided the respondents according to experience into three groups. The first group is $1-5$ years, the second group is $5-10$ years, and the third group is above 

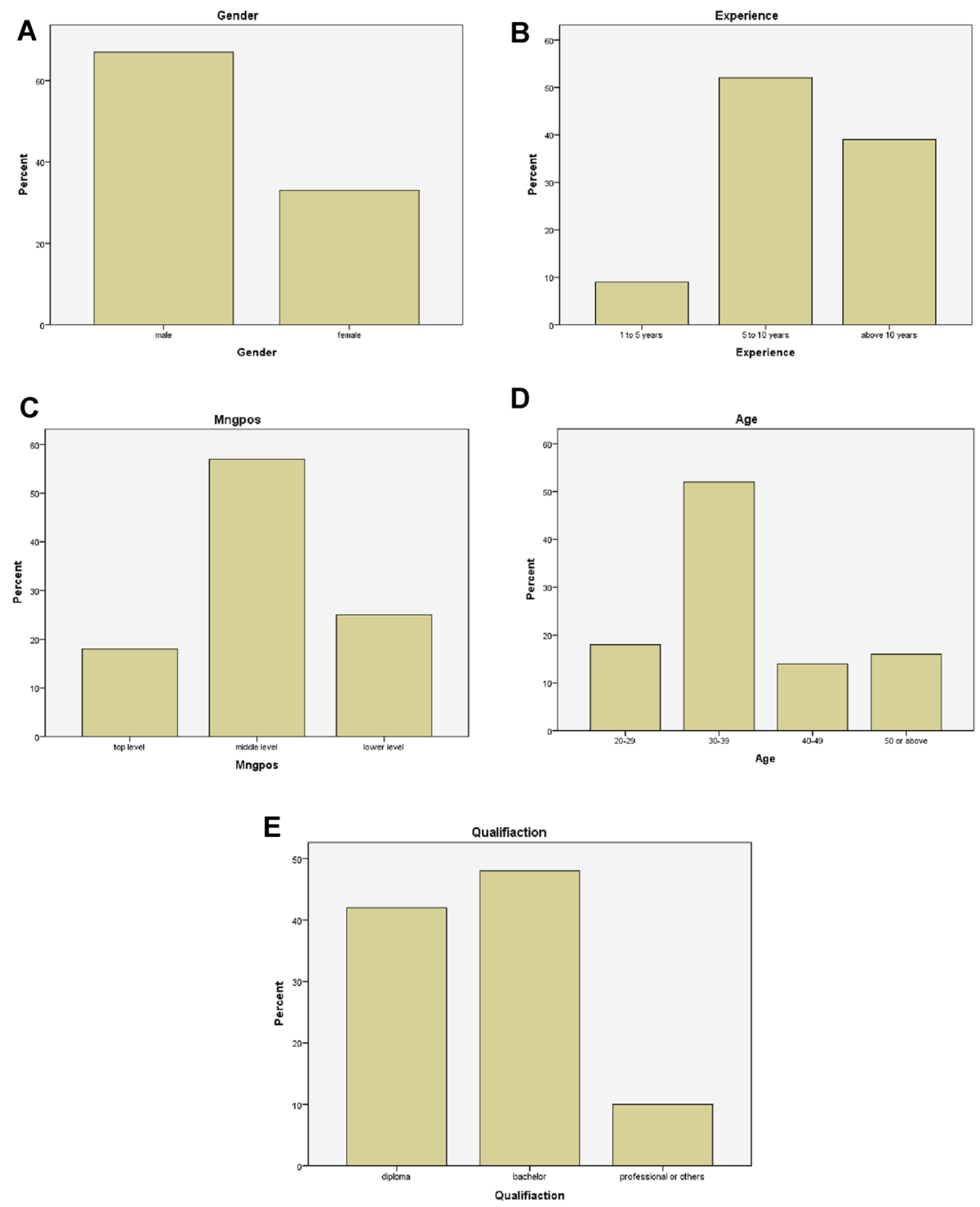

Fig. 1 a male and female ratio of respondents, $\mathbf{b}$ experience levels of respondents( 1 to 5 years, 5 to 10 years and above 10 years), c Managerial positions of respondents(top-level management, middle-level management, and lower-level management), d age levels of respondents(20-29. 30-39, 40-49, 50 and above). e qualification of respondents( diploma, bachelor degree, and other professional courses)

10 years of experience. It is shown in the graph that near about $10 \%$ of the sample is coming under 1st group, more than 50\% are coming under 2nd group and $40 \%$ of the samples are under 3rd group.

In Fig. 1c, according to managerial positions respondents are divided into three groups namely top level, middle level, and lower level of management that has been explained. The majority comes under middle-level management, and then near about 30 
percent is under lower level and others less than $20 \%$ are top-level management. If we consider any organization we can observe the positions at the top level are relatively less than the middle and lower level of management. In Fig. 1d, the age of the respondents has been classified into four groups. The groups are namely, 20-29 years, 30-39 years, 40-49 years, and 50 years and above. Most of the respondents, above 50\% are coming under the 30-39 years age group. Very few respondents are coming under the 40-49 age group. Rest are considered in other groups. Figure 1e explains the level of qualification of real estate employees. It is seen that more than $40 \%$ are diploma holders, near about $50 \%$ bachelor degree holder in the construction-related field, other employees are in other professionals.

As we have mentioned earlier that to decrease the numbers of variables we have done a factor analysis test. The test results are shown below. KMO test, principal component analysis, and rotated component matrix have been shown below.

In Table 1, the KMO test allows us to ensure that the dataset is suitable to run the factor analysis test. The test statistic result should be $0-1$. In our dataset, the KMO and Bartlett's test is revealed that sampling adequacy is 0.520 , which means more than 0.50 , and the p-value is less than 0.05 , which is significant. Here, Df (degree of freedom) is 66. Therefore we can run factor analysis.

The above table (Table 2) is stated total variance explained through principal component analysis. PCA helps to represent a multivariate data table as a smaller set of variables. It explains the variance-covariance structure of a set of variables. It is a dimensionalityreduction technique. The above table total variance explained generates a smaller set of factors from large numbers of variables. Each of the factors is explaining a percent of the total variance. Here we can see the total values (eigenvalues) of factors are more than 1in each case, so we can take the first four components. If the eigenvalues of components are more than 1 it means the factors are taken into consideration for the study. Factors that are not able to explain much variance may not be worth including the final model. The total variance explains is more than $80 \%$. Therefore, the association of variables to generate the factor is good for the studyThe rotated component matrix helps to determine what the components represent.. In our study Table 3 shows that the rotated component matrix generates four factors from twelve variables (Debbarma and Durai 2021; Kathuria and Kumar 2021).

The first factor consists of four variables namely, employee morale, mental health, online learning opportunity, and safety measures. The second factor consists of insurance coverage, termination, organizational commitment, and career planning of employees. The third factor consists of three variables, namely recruitment process, employees' performance, and bonus. The last and fourth factor is consisting of one variable, that is pay cut, as the last component value (eigenvalue) is greater than 1 that we have got from the total variance explained table(Table 2), therefore we are considering one variable as one factor. It is noted that the eigenvalue should be 1 or more than that, which means the factor is highly considered.

Table 1 KMO and Bartlett's test

\begin{tabular}{lll}
\hline Kaiser-Meyer-Olkin measure of sampling adequacy & $\mathbf{. 5 2 0}$ \\
\hline Bartlett's test of sphericity & Approx. Chi- & 1067.302 \\
& SQUARE & \\
& Df & 66 \\
& Sig & $\mathbf{. 0 0 0}$ \\
\hline
\end{tabular}




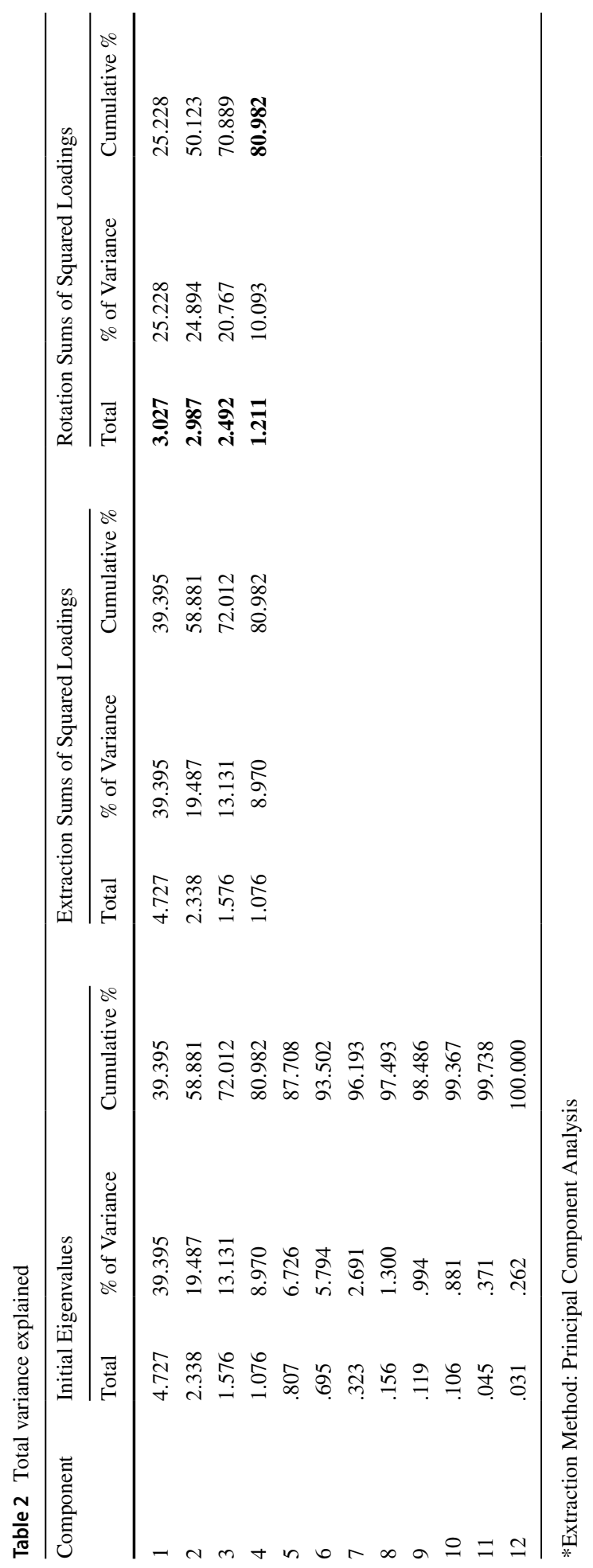


Table 3 Rotated Component Matrix

\begin{tabular}{|c|c|c|c|c|}
\hline & \multicolumn{4}{|c|}{ Component } \\
\hline & 1 & 2 & 3 & 4 \\
\hline Morale & .839 & & & \\
\hline Mental health & .746 & & & \\
\hline Online learn & .737 & & & \\
\hline Safety & .699 & & & \\
\hline Insurance & & .864 & & \\
\hline Termination & & -.816 & & \\
\hline Commitment & & .792 & & \\
\hline Career plan & & .788 & & \\
\hline Recruitment & & & .946 & \\
\hline Performance & & & .892 & \\
\hline Bonus & & & -.647 & \\
\hline Paycut & & & & .891 \\
\hline
\end{tabular}

*Extraction Method: Principal Component Analysis

*Rotation Method: Varimax with Kaiser Normalization

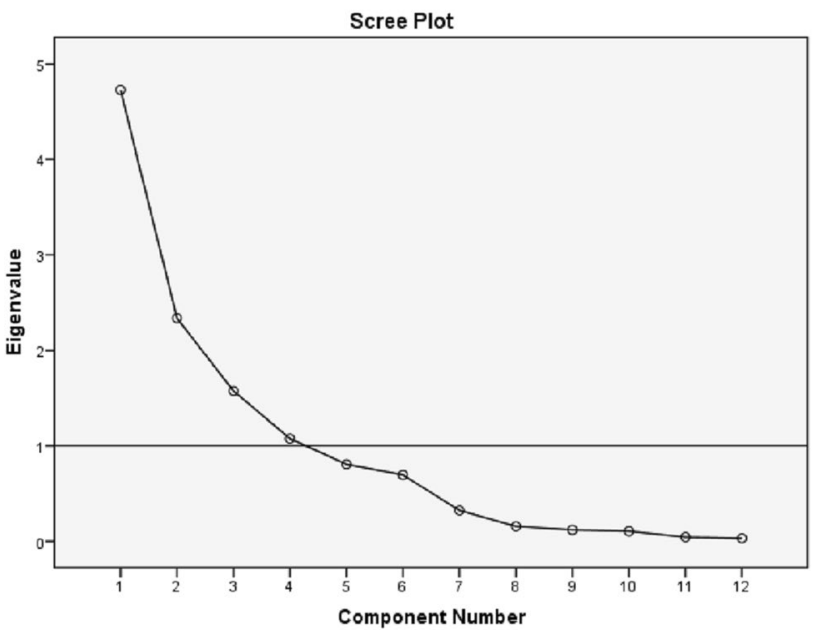

Fig. 2 Scree plot under factor analysis

Scree plot under factor analysis is reported in Fig: 2. In this graph, the four factors consisting of variables that we have considered in our study have been shown. We have taken the eigenvalue 1 , the standard. Therefore four factors take the position above the eigenvalue line (1).

The one way ANOVA has shown in Table 4, we have named the four factors like employees' health and safety, employees' retention level, employees' performance, and pay deduction of employees. Here it is showing us there are two factors employee' health and safety and employee performance have a significant impact on the quality of work-life of the real estate 
Table 4 ANOVA

\begin{tabular}{lllllll}
\hline & & Sum of Squares & Df & Mean Square & F & Sig \\
\hline Health safety & Between Groups & 10.469 & 2 & 5.234 & 8.932 & $\mathbf{. 0 0 0}$ \\
& Within Groups & 56.843 & 97 & .586 & & \\
& Total & 67.312 & 99 & & & \\
Retention & Between Groups & 1.630 & 2 & .815 & .903 & .155 \\
& Within Groups & 41.527 & 97 & .428 & & \\
Performance & Total & 43.157 & 99 & & & \\
& Between Groups & 6.778 & 2 & 3.389 & & $\mathbf{. 0 0 0}$ \\
& Within Groups & 24.814 & 97 & .256 & & .063 \\
& Total & 31.592 & 99 & & \\
& Between Groups & 9.851 & 2 & 4.926 & & \\
\hline
\end{tabular}

*Significant at the 0.05 level

employees. At the level of 5\% significance, the value of $\mathrm{F}$ statistics is significant in our study in the case of the first and third dependent factors; the F statistics values are 8.932 and 13.248 respectively. The degree of freedom is $2\left[\mathrm{df}_{(\mathrm{n}-1)=(3-1)=2}\right]$ as there are three groups on level of experience. According to the level of experience of the employees the dependent variables are explained. When the work of the real estate sector is going along with the pandemic situation, more and more people are affected by the new normal, based on workplace policies that have framed by the various organization in real estate sectors related to the quality of work-life. In this scenario, we can say the work-life quality is going to hamper as the economy is falling due to the adverse effect of the pandemic. Whenever we are considering the sample in our study it is revealed that health and safety including taking care of the mental health of employees by the management influence the employee's work-life a lot to keep them productive. Effective ways of recruitment with using artificial intelligence-driven technology in the staffing process in this situation make another good impact on the quality of work life. Though pay cut policy exists as no such economic development takes place but if management introduces an additional pay or bonus or an effective reward system that will help to boost employees' performance in this crisis.

We have compared the three levels of experience groups on the basis of dependent variables side by side in Table 5 (Bonferroni test). It has been observed from the table that the dependent variable health and safety has a significant impact on the people for all three groups having experiences of less than 5 years, 5-10 years and above 10 years in real estate during this pandemic state. Employee performance related variables are impactful for two groups having experiences of 5-10 years and above 10 years. Other variables are not significant on the levels of experience of the respondents.

\section{Findings and discussions}

In this findings section, we will say that we have considered four factors from twelve variables on the quality of work life. Among the four, two factors are significant in our study. It is shown those employees' safety issues, taking care of mental health, learning 


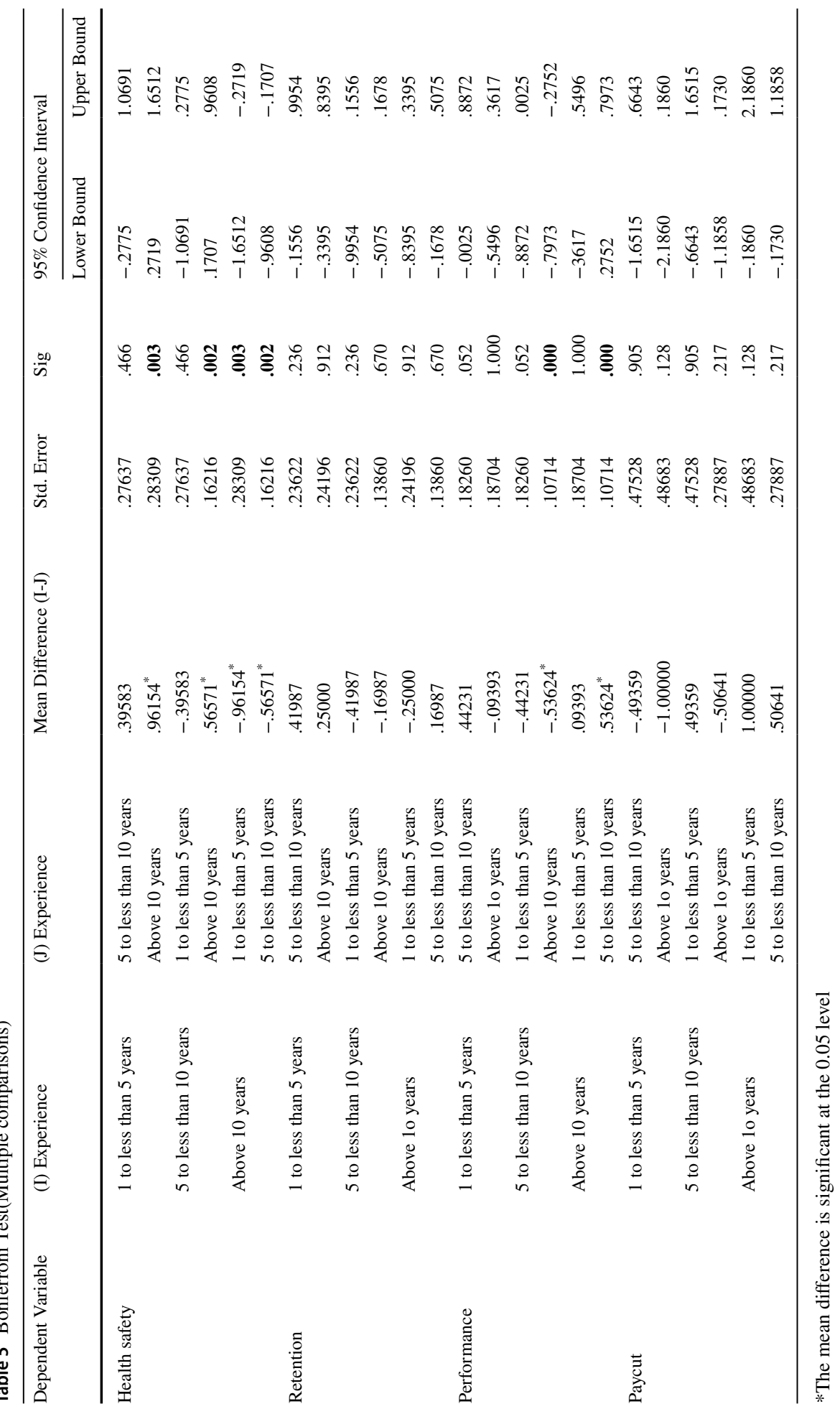


opportunities are boosting the employees' morale a lot in this new normal. Though pay deduction is taking place in some of the real estate companies, it is not so much impactful on employees' performance, as they are well aware of the economic deprivation. Despite that, a good reward system can change the quality of work-life in the COVID-19 situation. We mentioned in our null hypothesis area that there is no relation between the pandemic situation and the quality work-life of real estate professionals in Kolkata,India. After analysing the collected data from real estate firms it is notified that quality of work-life a significant impact on the different levels of experience of the respondents. We have done a factor analysis test on twelve variables of quality of work-life, and the result has been generated into four factors that we have considered in the ANOVA test. The test has revealed that the dependent variable health and safety has a significant impact on the people for all three groups having experiences of less than 5 years, 5-10 years and above 10 years in real estate during this pandemic state. Employee performance related variables are impactful for two groups having experiences of 5-10 years and above 10 years. It means medium and high experience groups are considered. Here the first group of respondents has been eliminated which means employees who have less than 5 years of experience. It can be said that less experience level does not have any direct relation with the quality of work-life parameters in COVID-19 (Borra and Dey 2020; Borra 2020). Other factors like employees' retention level and pay deduction are not significant on the levels of experience of the respondents. Therefore we can say that the alternative hypothesis is accepted in this study.

\section{Conclusions}

Quality of work life is a symbol of employee involvement in the organization that consists of methods of motivation for human resources. It is the response of employers based on the employee's needs. It helps to build a good relationship between employers and employees. For retaining good talent, organizations must possess a low-stress level and high quality of work life. Employees are the assets of the organization, by making them satisfied the company can achieve its short term as well as its long term goals. During the situation of COVID-19 pandemic decency of work, life is getting hampered. The management should give a deep focus on employees' work-life not only during this crisis period but afterward also. The revenue earning of a company is linked to the job satisfaction of its employees. A company that doesn't give focus on employee satisfaction may face severe problems like increasing turnover of manpower, diminishing productivity, poor performance level, and limited power to attract and retain a talented workforce. Whenever it comes to the COVID -19 situations, it is a very obvious thing that due to economical degradation many companies of the real estate sector cannot maintain the quality of the work-life of employees as a true sense. The real estate sector is generating a high level of the workforce in the market, therefore the firms need to treat this manpower as assets throughout the new normal period. We may conclude to make the work-life better in this epidemic time, more the techniques of artificial intelligence need to be incorporated in business organizations. In this work, quality of work-life based on age, gender, and management level is not reported. A very limited number of factors of quality of work-life (only related to pandemic) have been reported. Besides real estate employees (top, middle, and lower level of management), construction workers can be considered and compared in further studies. In cross-sectional data analysis, the temporal link between the outcome and the exposure cannot be determined because 
both are examined at the same time. To avoid this limitation time-series data analysis can also be studied in the future.

\section{References}

Avkiran, N.K.: Rising productivity of Australian trading banks under deregulation 1986-1995. J. Econo. mics and Finance 24(2), 122-140 (2000)

Baily, M.N., Bartelsman, E.J., Haltiwanger, J.: Downsizing and productivity growth: myth or reality? Small Bus. Econ. 8(4), 259-278 (1996)

Borra, S. (2020). COVID-19 apps: Privacy and security concerns. In Intelligent Systems and Methods to Combat Covid-19 (pp. 11-17). Springer, Singapore.

Borra, S., Dey, N.: Misinformation About COVID-19 and Confidential Information Leakage: Impacts on the Psychological Well-being of Indians. Current Psychiatry Research and Reviews Formerly: Current Psychiatry Reviews 16(4), 283-287 (2020)

Dahlin, M., Joneborg, N., Runeson, B.: Stress and depression among medical students: A cross-sectional study. Med. Educ. 39(6), 594-604 (2005)

Debbarma, I., Durai, T.: Educational disruption: Impact of COVID-19 on students from the Northeast states of India. Child Youth Serv. Rev. 120, 105769 (2021)

Dey, N., Hassanien, A.E., Bhatt, C., Ashour, A., Satapathy, S.C. (eds.): Internet of things and big data analytics toward next-generation intelligence, pp. 3-549. Springer, Berlin (2018)

Fong, S. J., Dey, N., \& Chaki, J. (2020). Artificial intelligence for coronavirus outbreak, Springer Nature.

Grachev, M., Rakitsky, B.: Historic horizons of Frederick Taylor's scientific management. J. Manag. Hist. 19(4), 512-527 (2013)

Hackman, J.L., Oldhams, G.R.: Work Redisign. Addison-Wesley, Reading, M.A (1980)

https://hr.nih.gov/workforce/workforce-planning (Last access date: 02/11/2020).

https://mitrefinch.com/blog/5-simple-steps-workforce-planning/ (Last access date: 29/10/2020).

Jaiswal, A., \& Arun, C. J. (2020). Unlocking the COVID-19 Lockdown: Work from Home and Its Impact on Employees.

Joshi, A., Dey, N., \& Santosh, K. C.(2020) Intelligent Systems and Methods to Combat Covid-19. SpringerBriefs in Computational Intelligence. eBook ISBN, 978-981

Kathuria, K., \& Kumar, N. (2021). Factors Affecting Import Demand in India: A Principal Component Analysis Framework. In Advances in Manufacturing and Industrial Engineering (pp. 585-595). Springer, Singapore.

Khan, R.A.G., Khan, F.A., Khan, M.A., Shakeel, M.: Impact of flexible scheduling on employee performance regarding stress and work-family conflict. Far East Journal of Psychology and Business 4(3), $1-14$ (2011)

Kraemer, K.L., Danziger, J.N.: The impacts of computer technology on the worklife of information workers. Soc. Sci. Comput. Rev. 8(4), 592-613 (1990)

Kravchik, M., \& Shabtai, A. (2021). Efficient cyber attack detection in industrial control systems using lightweight neural networks and pca. IEEE Transactions on Dependable and Secure Computing.

Lawler, E.E (1975) "Measuring the psychological quality of working life: The why and how of it, in L.E Davis and A.B. Cherns (Ed.), The Quality of Working Life, 1, 123-133, New York: Free Press

Lawler, E.E., III.: Strategies for Improving the Quality of Work Life. Am. Psychol. 37, 486-693 (1982)

Locke, E. A. (1982). The ideas of Frederick W. Taylor: an evaluation. Academy of management review, 7(1), $14-24$.

Mayer-Schonberger, V., \&Cukier, K. (2013). Big data: the essential guide to work, life and learning in the age of insight. Hachette UK.

Md-Sidin, S., Sambasivan, M.: Relationship between work-family conflict and quality of life: an investigation into the role of social support. J. Manag. Psychol. 25(1), 58-81 (2010)

Milligan, P., Njie, A., Bennett, S.: Comparison of two cluster sampling methods for health surveys in developing countries. Int. J. Epidemiol. 33(3), 469-476 (2004)

Mitcham 2005, p. 1153 Mitcham, Carl and Adam, Briggle Management in Mitcham (2005) p. 1153

Muchinsky, P.M.: Employee absenteeism: A review of the literature. J. Vocat. Behav. 10(3), 316-340 (1977)

Naithani, D.: Recession and work-life balance initiatives. Naithani, P. (2010) . Recession and work-life balance initiatives. Romanian Economic Journal 37, 55-68 (2010)

Nandi, D., Ashour, A.S., Samanta, S., Chakraborty, S., Salem, M.A., Dey, N.: Principal component analysis in medical image processing: a study. International Journal of Image Mining 1(1), 65-86 (2015)

Phadtare, M.T.: Strategic management: concepts and cases. PHI Learning Pvt, Ltd (2010) 
Ralston, D.A., Flanagan, M.F.: The effect of flextime on absenteeism and turnover for male and female employees. J. Vocat. Behav. 26(2), 206-217 (1985)

Saklani D.R., (2004), Quality of Work Life in the Indian Context: An Empirical Investigation, Decision, vol. 31, no. 2, July-December, pp. 101-135.

Sandrick K., (2003), Putting the emphasis on employees as an award. Winning employer, Baptist health care has distant memories of the workforce shortage, Trustee, January, pp. 6-10.

Shinde, G.R., Kalamkar, A.B., Mahalle, P.N., Dey, N.: Data Analytics for Pandemics: A COVID-19 Case Study. CRC Press (2020a)

Shinde, G.R., Kalamkar, A.B., Mahalle, P.N., Dey, N., Chaki, J., Hassanien, A.E.: Forecasting models for coronavirus disease (COVID-19): a survey of the state-of-the-art. SN Computer Science 1(4), 1-15 (2020b)

Sirgy, M.J., Efraty, D., Siegel, P., Dong-Jin, L.: A New Measure of Quality of Work Life (Qwl) Based on Need Satisfaction and Spillover Theories. Soc. Indic. Res. 55, 241-302 (2001)

Srivastava, S., Kanpur, A.: A study on quality of work life: key elements \& It's Implications. IOSR-JBM 16(3), 54-59 (2014)

Swarnalatha.V and Lalitha.P(2020). Work-Life Balance In Pandemic: A Conceptual Study of Problems and Challenges Faced by Working Women Professionals, Mukt Shabd Journal.

Virmani, J., Dey, N., \& Kumar, V. (2016). PCA-PNN and PCA-SVM based CAD systems for breast density classification. In Applications of intelligent optimization in biology and medicine (pp. 159-180). Springer, Cham.

Westwood, J. A., \&Cazier, J. A. (2016, January). Work-life optimization: Using big data and analytics to facilitate work-life balance. In 2016 49th Hawaii International Conference on System Sciences (HICSS) (pp. 1701-1709).IEEE.

Publisher's Note Springer Nature remains neutral with regard to jurisdictional claims in published maps and institutional affiliations. 